\title{
Classification, diagnosis and potential mechanisms in Pontocerebellar Hypoplasia
}

\author{
Yasmin Namavar ${ }^{1}$, Peter G Barth², Bwee Tien Poll-The ${ }^{2}$ and Frank Baas ${ }^{1 *}$
}

\begin{abstract}
Pontocerebellar Hypoplasia $(\mathrm{PCH})$ is group of very rare, inherited progressive neurodegenerative disorders with prenatal onset. Up to now seven different subtypes have been reported (PCH1-7). The incidence of each subtype is unknown. All subtypes share common characteristics, including hypoplasia/atrophy of cerebellum and pons, progressive microcephaly, and variable cerebral involvement. Patients have severe cognitive and motor handicaps and seizures are often reported. Treatment is only symptomatic and prognosis is poor, as most patients die during infancy or childhood. The genetic basis of different subtypes has been elucidated, which makes prenatal testing possible in families with mutations. Mutations in three tRNA splicing endonuclease subunit genes were found to be responsible for $\mathrm{PCH} 2, \mathrm{PCH} 4$ and $\mathrm{PCH}$. Mutations in the nuclear encoded mitochondrial arginyl- tRNA synthetase gene underlie PCH6. The tRNA splicing endonuclease, the mitochondrial arginyl- tRNA synthetase and the vaccinia related kinase 1 are mutated in the minority of $\mathrm{PCH} 1$ cases. These genes are involved in essential processes in protein synthesis in general and tRNA processing in particular. In this review we describe the neuroradiological, neuropathological, clinical and genetic features of the different PCH subtypes and we report on in vitro and in vivo studies on the tRNA splicing endonuclease and mitochondrial arginyl-tRNA synthetase and discuss their relation to pontocerebellar hypoplasia.
\end{abstract}

\section{Review}

\section{Pontocerebellar Hypoplasias}

The name Pontocerebellar Hypoplasia $(\mathrm{PCH})$ originates from a report of Brun almost a century ago, in which he described human brain development and abnormalities associated with brain development. Cerebellar Hypoplasia is described as dwarfed growth of the cerebellum [1]. Seven years later Brouwer suggested that pontocerebellar hypoplasia is possibly due to degeneration rather than to hypoplasia [2]. Subsequent reports described the pathology as atrophy of cerebellar hemispheres with relative sparing of the flocculi and vermis and apparent fragmentation of the cerebellar dentate nucleus [3-5]. The first reported case of $\mathrm{PCH}$ which included specific clinical details was probably by Krause [4]. He reported a child with swallowing problems, spasticity and complete absence of cognitive and voluntary motor development with the pathological profile of $\mathrm{PCH}$. In retrospect this may have been the first documented case on $\mathrm{PCH}$

\footnotetext{
* Correspondence: f.baas@amc.uva.nl

'Department of Genome Analysis, Academic Medical Center, University of Amsterdam, Meibergdreef 9, 1105 AZ Amsterdam, The Netherlands Full list of author information is available at the end of the article
}

type 2. Pfeiffer and Pfeiffer first reported the extrapyramidal component [5-8]. Barth et al. described a cluster of related families with $\mathrm{PCH}$ from a genetic isolate in the Netherlands as an inherited syndrome of microcephaly, dyskinesia and pontocerebellar hypoplasia [9]. A first attempt for classification was based on two subtypes; this divided $\mathrm{PCH}$ in cases with accompanying spinal anterior horn disease (type 1) and cases with chorea/dyskinesia (type 2) [10]. This classification was extended into five subtypes in 2006 and in 2007 a sixth was added $[11,12]$. The latest subtype that may be classified as $\mathrm{PCH} 7$, has been recently added to this list [13]. PCH now includes seven (PCH1-7) disorders. In most cases, especially in $\mathrm{PCH} 1, \mathrm{PCH} 2, \mathrm{PCH} 4$ and $\mathrm{PCH} 5$ prenatal onset of structural decline is well documented. In some milder cases cerebellar images suggest a perinatal or early postnatal onset. The clinical diagnosis is made on neuroradiological, neuropathological and neurological findings [14-18]. Neuroradiological findings in all subtypes are pontocerebellar hypoplasia and atrophy of ventral pons, cerebellum and to a lesser extent also the cerebral cortex (Figure 1). Neuropathologically, there is segmental degeneration of the cerebellar cortex with

\section{() Biomed Central}



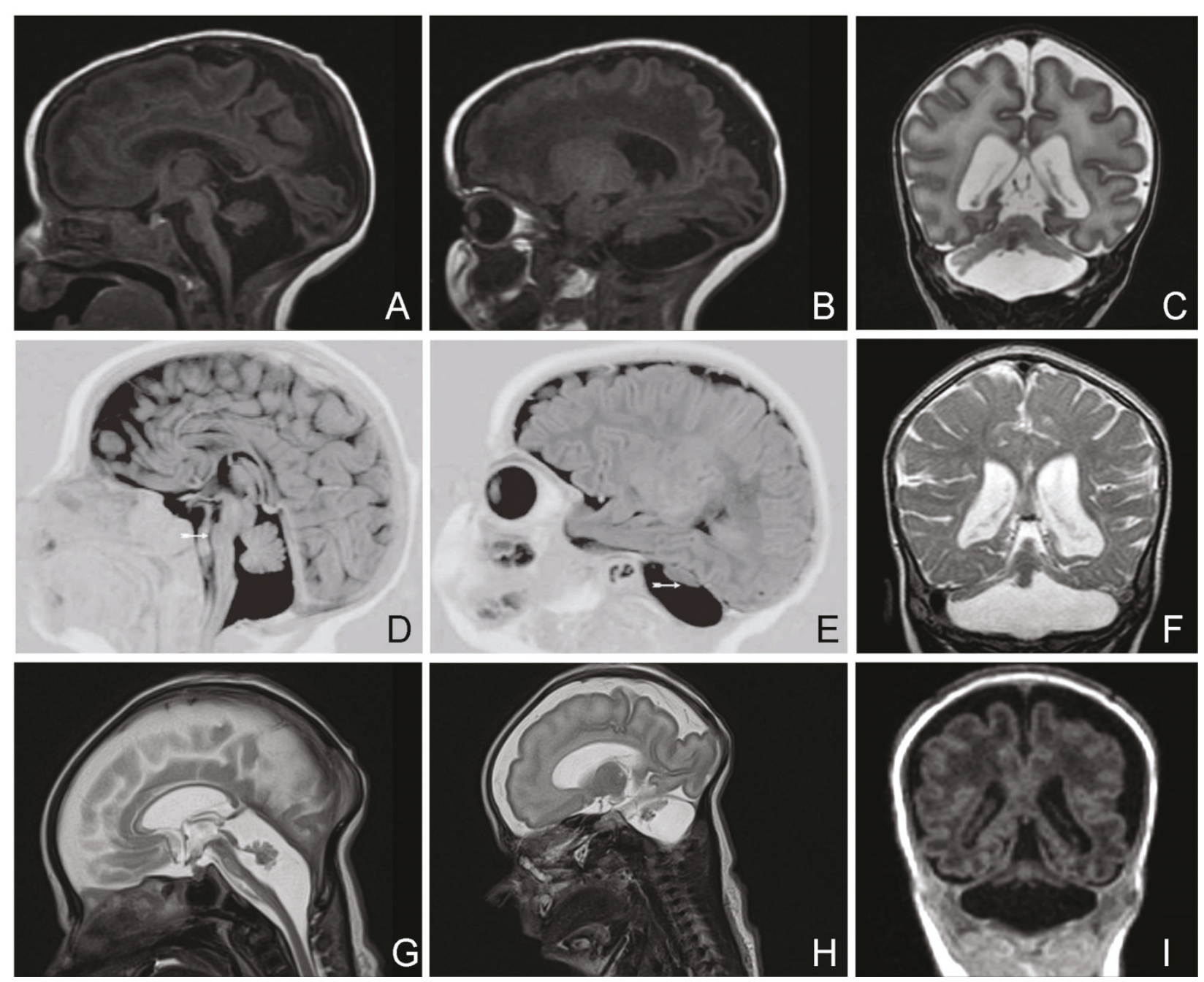

Figure 1 MRI sections of cases with PCH type 1, type 2 and type 4 . The images of the PCH1 case were kindly provided by Professor Darin, The Queen Silvia. Children's Hospital, Gothenburg University, Sweden. 1A-C: Images of a 2 wk old neonate with PCH1. 1A: Mid-sagittal section (T1) shows vermal hypoplasia and marked cerebellar hypoplasia. 1B: Lateral sagittal section (T1) shows severe hypoplasia of the cerebellar hemispheres. 1C: Coronal section (T2) shows flattened cerebellar hemispheres which also display some atrophy. The vermis is relatively spared. 1D-E: Images of a 2 months old baby with PCH2. 1D: Mid-sagittal section (T1IR) shows a flat ventral pons and vermal hypoplasia. 1E: Lateral sagittal section (T1IR) shows severely hypoplastic cerebellar hemispheres (arrow) leaving most of the posterior fossa empty. 1F: Coronal section (T2) of a 9 months old infant with PCH2 shows flat cerebellar hemispheres and mild vermal hypoplasia (dragonfly configuration). Cerebral cortical atrophy is also present. 1G-I: Images of a 31+5 weeks neonate with PCH4. 1G: Mid-sagittal section (T2) shows severe vermal hypoplasia and ventral pontine flattening. $\mathbf{1 H}$ : Lateral sagittal section (T2) shows severe hypoplasia of the cerebellar hemispheres. Above the tentorium there is an increased distance between the cortical surface and the skull visible, which is probably due to diminished brain growth in utero. 1l: Coronal section (T1) shows extremely small and flattened cerebellar hemispheres and severe vermal hypoplasia. Immaturity of cerebral cortex and enlarged ventricles are also visible.

loss of Purkinje cells, fragmentation of the dentate nucleus and degeneration with neuronal loss and decreased folding of the inferior olivary nuclei in $\mathrm{PCH} 1$, $\mathrm{PCH} 2, \mathrm{PCH} 4$ and PCH5. Neuropathological studies in the other types are scarce or absent. Cerebellar hemispheres are usually more severely affected than the vermis and there is progressive loss of the ventral nuclei and transverse fibers in the pons [19]. Furthermore there is severe progressive microcephaly and variable ventriculomegaly. Severe intellectual deficit, swallowing problems and seizures are clinical features of all subtypes $[9,18,20]$.

\section{Clinical features of the $\mathrm{PCH}$ subtypes \\ $\mathrm{PCH} 1$}

$\mathrm{PCH}$ type 1 (Table 1) (PCH1, previously known as Norman's disease, ORPHA2254, MIM 607596) is characterized by pontocerebellar hypoplasia with additional loss 
Table 1 PCH subtypes.

\begin{tabular}{|c|c|c|c|c|}
\hline $\mathrm{PCH}$ & Clinical features & Pathological features & Gene(s) & Ref. \\
\hline $\mathrm{PCH} 1$ & $\begin{array}{l}\text { Neonatal period: Hypotonia, impaired } \\
\text { swallowing, congenital contractures } \\
\text { and/or polyhydramnios, primary } \\
\text { hypoventilation, progressive } \\
\text { microcephaly. } \\
\text { MRI: Pontocerebellar hypoplasia. }\end{array}$ & $\begin{array}{l}\text { Cerebellar hypoplasia: hemispheres }>> \\
\text { vermis, areas of stunted or absent folial } \\
\text { development. Cerebellar dentate nucleus } \\
\text { present as tiny remnants. } \\
\text { Olivary nucleus: absent folding and } \\
\text { gliosis. } \\
\text { Pons: loss of ventral nuclei and } \\
\text { transverse fibers. } \\
\text { Spinal cord: Anterior horn cell } \\
\text { degeneration. } \\
\text { Peripheral nerves and muscle: chronic } \\
\text { denervation. }\end{array}$ & $\begin{array}{l}\text { One family with the common TSEN54 } \\
\text { mutation. } \\
\text { One case with missense plus splice } \\
\text { site mutations in RARS2. } \\
\text { One atypical mild family with } \\
\text { nonsense mutations in VRK1. } \\
\text { Locus unknown in the majority. }\end{array}$ & {$[6,7,10,20,21,40,42]$} \\
\hline$\overline{\mathrm{PCH} 2}$ & $\begin{array}{l}\text { Neonatal period: Clonus, impaired } \\
\text { swallowing. } \\
\text { Infancy and later: Chorea, variable } \\
\text { spastic pareses; progressive } \\
\text { microcephaly. Severe impairment of } \\
\text { cognitive and motor development. } \\
\text { MRI: Variable neocortical atrophy, } \\
\text { pontocerebellar hypoplasia. }\end{array}$ & $\begin{array}{l}\text { Cerebellar hypoplasia: hemispheres }>> \\
\text { vermis. Segmental degeneration of } \\
\text { cerebellar cortex. Fragmentation of } \\
\text { cerebellar dentate nucleus. } \\
\text { Olivary nucleus: neuron loss and } \\
\text { decreased folding. } \\
\text { Pons: progressive loss of ventral nuclei } \\
\text { and transverse fibers. } \\
\text { Cerebral cortex: progressive atrophy }\end{array}$ & $\begin{array}{l}\text { TSEN54: p.A307S, A307S most common } \\
\text { in } 75 \text { families. } \\
\text { Rarely: Other TSEN54 missense } \\
\text { mutations in } 3 \text { families, TSEN2 } \\
\text { mutations in } 2 \text { families, TSEN34 } \\
\text { mutations in } 1 \text { family. }\end{array}$ & {$[15,18-20,28,37]$} \\
\hline $\mathrm{PCH} 3$ & $\begin{array}{l}\text { Neonatal period: Hypotonia, impaired } \\
\text { swallowing. } \\
\text { Infancy and later: Short stature } \\
\text { progressive microcephaly, optic } \\
\text { atrophy. } \\
\text { MRI: Neocortical and cerebellar } \\
\text { atrophy, pontocerebellar hypoplasia; } \\
\text { Pons and cerebellum equally affected. }\end{array}$ & No autopsies performed. & $\begin{array}{l}\text { Locus on chromosome } 7 \mathrm{q} \text { in } 2 \\
\text { families. }\end{array}$ & [30-32] \\
\hline $\mathrm{PCH} 4$ & $\begin{array}{l}\text { Neonatal period: Hypertonia, severe } \\
\text { clonus, polyhydramnios and/or } \\
\text { contractures; primary hypoventilation. } \\
\text { MRI: Delayed neocortical maturation, } \\
\text { pontocerebellar hypoplasia; } \\
\text { microcephaly on autopsy. }\end{array}$ & $\begin{array}{l}\text { Cerebellar hypoplasia: hemispheres }>> \\
\text { vermis, areas of stunted or absent folial } \\
\text { development. Cerebellar dentate nucleus } \\
\text { present as tiny remnants } \\
\text { Olivary nucleus: absent folding and } \\
\text { gliosis. } \\
\text { Pons: loss of ventral nuclei and } \\
\text { transverse fibers. }\end{array}$ & $\begin{array}{l}\text { TSEN54: Compound heterozygosity for } \\
\text { p.A307S plus nonsense or splice site } \\
\text { mutations in } 10 \text { families. Three } \\
\text { missense mutations in } 1 \text { family. }\end{array}$ & {$[14,16,19,20,37]$} \\
\hline $\mathrm{PCH} 5$ & $\begin{array}{l}\text { Prenatal/neonatal period: Clonus or } \\
\text { seizures. } \\
\text { Neonatal period: Persistent clonus, } \\
\text { microcephaly and pontocerebellar } \\
\text { hypoplasia on autopsy. }\end{array}$ & $\begin{array}{l}\text { Cerebellar hypoplasia: cortical } \\
\text { involvement as in } \mathrm{PCH} 4 \text {, but vermal } \\
\text { cortex more extensively affected than } \\
\text { hemispheric cortex; subtotal loss of } \\
\text { cerebellar dentate nucleus. } \\
\text { Olivary nucleus: absent folding. } \\
\text { Pons: loss of ventral nuclei and } \\
\text { transverse fibers. }\end{array}$ & $\begin{array}{l}\text { TSEN54: Compound heterozygosity } \\
\text { for p.A307S plus splice site mutation } \\
\text { in } 1 \text { family. }\end{array}$ & {$[11,20]$} \\
\hline $\mathrm{PCH} 6$ & $\begin{array}{l}\text { Neonatal period: Hypotonia, clonus, } \\
\text { impaired swallowing. } \\
\text { Infancy and later: Progressive } \\
\text { microcephaly, spasticity, elevated CSF } \\
\text { lactate, edema of extremities. } \\
\text { MRI: Neocortical and cerebellar } \\
\text { atrophy, pontocerebellar hypoplasia; } \\
\text { Pons and cerebellum equally affected. }\end{array}$ & No autopsies performed. & $\begin{array}{l}\text { Missense and splice site mutations in } \\
\text { RARS2 in } 2 \text { families. }\end{array}$ & {$[12,39]$} \\
\hline $\mathrm{PCH} 7$ & $\begin{array}{l}\text { Neonatal period: No palpable gonads } \\
\text { with a micropenis. Hypotonia. } \\
\text { Infancy and later: Regression of penis. } \\
\text { Progressive microcephaly, seizures, } \\
\text { respiratory distress, poor feeding. } \\
\text { MRI: Pontocerebellar hypoplasia. }\end{array}$ & $\begin{array}{l}\text { Cerebellar hypoplasia: absence of } \\
\text { cerebellar hemispheres with neuronal } \\
\text { loss. } \\
\text { Olivary nucleus: absent. } \\
\text { Pons: loss of ventral nuclei and } \\
\text { transverse fibers. } \\
\text { Cerebral cortex: progressive atrophy. }\end{array}$ & No locus. & [13] \\
\hline
\end{tabular}

Adapted and extended from Namavar et al. [38]. 
of motor neurons in the anterior horn of the spinal cord, pathologically similar to the spinal muscular atrophies (SMA) [6,7]. Magnetic resonance imaging (MRI) of $\mathrm{PCH} 1$ patients always shows cerebellar hypoplasia in which the cerebellar hemispheres are variably affected; in some cases more flat and in other cases more preserved (Figure 1A-C). There is variable involvement of pons and cerebrum [21]. Patients suffer from severe hypotonia, pareses, central visual failure, dysphagia, respiratory insufficiency, psychomotor retardation and they usually die within the first year. The majority of patients also exhibits prenatal onset of symptoms such as congenital contractures and polyhydramnios. Microcephaly in most reported cases is not present at birth, but develops postnatally $[7,10,21-25]$.

\section{$\mathrm{PCH} 2$}

PCH type 2 (PCH2, ORPHA2524, MIM 277470, 612389, $612390)$ is the most frequently reported and therefore the best studied subtype (Table 1) [10,18-20,26]. So far at least 81 families have been reported [20,27,28]. Extrapyramidal dyskinesias and dystonia are the major features of $\mathrm{PCH} 2$, pure spasticity is reported in a minority. Other clinical features include impairment of swallowing from birth on, jitteriness in the neonatal period, central visual failure and seizures. There is no involvement of the spinal anterior horn cells in any of the cases that have been studied post-mortem. Life expectancy is unpredictable, as age of death ranges from the neonatal period to well into adulthood; most patients however do not reach puberty [20]. Recently chances for survival have become greater due to improved care, such as tube feeding and gastrostomy. Typical brain MRI findings are a dragonfly-like cerebellar pattern on coronal sections, in which the cerebellar hemispheres are flat and severely reduced in size and the vermis is relatively spared (Figure 1D, E, F) [20]. Mild or severe atrophy of the cerebral cortex is observed in $40 \%$ of the $\mathrm{PCH} 2$ cases. On MRI myelination is delayed, but demyelination has not been observed [20].

Prenatal diagnosis by ultrasound imaging is not yet possible in the second trimester of pregnancy, therefore molecular genetic testing is required for prenatal diagnosis in high risk pregnancies [29].

\section{$\mathrm{PCH} 3$}

PCH type 3 (PCH3, ORPHA97249, MIM 608027) also known as cerebellar atrophy with progressive microcephaly (CLAM), is a very rare subtype of PCH (Table 1). Only three families have been described so far. All cases had short stature, seizures, hypotonia and in four of the five cases optic atrophy was reported [30-32]. In the most recent reported case, the patient suffered from an additional severe Vitamin A deficiency with unknown cause [32].

\section{$\mathrm{PCH} 4$}

$\mathrm{PCH}$ type 4 ( $\mathrm{PCH} 4$, olivopontocerebellar hypoplasia (OPCH), ORPHA166063, MIM 225753) shares similarities with $\mathrm{PCH} 2$; however $\mathrm{PCH} 4$ is more rare and the disease course is more severe (Table 1 ). Up to now 18 families have been reported with a $\mathrm{PCH} 4$ phenotype [14,16,20,28,33-36]. Patients exhibit more severe perinatal symptoms such as excessive, prolonged general clonus, congenital contractures, polyhydramnios and primary hypoventilation the latter necessitating prolonged mechanical ventilation. Weaning from ventilatory support is often impossible making survival through the neonatal period exceptional [20]. The pathology seen in $\mathrm{PCH} 4$ deviates in some regards from $\mathrm{PCH} 2$. A striking pathological distinction in $\mathrm{PCH} 4$ is the $\mathrm{C}$-shaped form of the inferior olives and large denuded areas without folia in the cerebellar hemispheric cortex, both phenomena suggesting an early prenatal onset $[14,19,37]$. Other striking features in $\mathrm{PCH} 4$ are pericerebral cerebrospinal fluid (CSF) accumulation, wide midline cava and delayed neocortical maturation; all suggesting prenatal decline of cerebral growth. Additionally the cerebellar vermis is more severely affected (Figure 1G, H, I) [20,38]. MRI analysis is therefore helpful in the clinical diagnosis of $\mathrm{PCH} 4$.

\section{PCH5}

Only one family with $\mathrm{PCH}$ type 5 (PCH5, ORPHA166068, MIM 610204) has been described (Table 1). In this subtype of $\mathrm{PCH}$, patients displayed fetal onset of seizure-like activity in combination with severe olivopontocerebellar hypoplasia and a severely affected cerebellar vermis [11]. Autopsy of the three published siblings showed diffuse brain volume loss, Cshaped inferior olivary nuclei, absent or immature dentate nuclei and cell death which was more pronounced in the cerebellar vermis than in the hemispheres. No evidence was found for spinal cord involvement.

In retrospect there is an arbitrary difference between $\mathrm{PCH} 4$ and $\mathrm{PCH} 5$ [38]. In $\mathrm{PCH} 5$ the vermis was more affected than the hemispheres, whereas in $\mathrm{PCH} 4$ the vermis and the hemispheres are both severely affected, with the emphasis on the hemispheres. The prenatal seizure-like activity observed in $\mathrm{PCH} 5$ appears similar to the severe neonatal clonus observed in $\mathrm{PCH} 4$ [16]. The primary hypoventilation observed in $\mathrm{PCH} 5$ is also a typical aspect of PCH4 [20].

\section{PCH6}

PCH type 6 (PCH6, ORPHA166073, MIM 611523) is a rare subtype of $\mathrm{PCH}$ (Table 1). The first published family with PCH6 is a Sephardic Jewish family with three siblings exhibiting cerebellar and vermal hypoplasia, infantile encephalopathy, dysphagia, seizures, progressive microcephaly and generalized hypotonia followed by spasticity [12]. No developmental milestones 
were reached. Biochemical investigation of mitochondrial complexes showed reduced activity of mitochondrial complexes I, III, and IV in muscle, while activity of complex II was normal. Elevated CSF lactate levels were found. Another case by Rankin et al. with a PCH6 phenotype in combination with progressive encephalopathy and edema, was suggestive of PEHO syndrome (Progressive Encephalopathy with Oedema, Hypsarrhythmia and Optic atrophy) [39]. No autopsies have been performed in $\mathrm{PCH} 6$ cases so far.

\section{$\mathrm{PCH} 7$}

A new subtype was proposed based on a profile combining genital abnormalities in combination with $\mathrm{PCH}$. We tentatively classify this as PCH7 (Table 1). The male patient had impalpable testes with a micropenis at birth and an $\mathrm{XY}$ karyotype. In the following weeks he developed progressive microcephaly, swallowing problems, hypotonia, respiratory distress, absent tracking movements, a head lag and seizures. MRI at the age of 16 weeks showed pontocerebellar hypoplasia and cerebral atrophy. At 19 weeks of age, regression of penile corporeal tissue was noted. He died at $51 / 2$ months of age [13].

\section{Genetics of PCH}

TSEN-related PCH and genotype-phenotype correlations

Through homozygosity mapping in a cluster of related families with $\mathrm{PCH} 2$, the genetic basis for $\mathrm{PCH} 2$ was identified [37]. All patients were homozygous mutant for an amino acid change of an alanine into a serine at position 307 (p.A307S, common mutation) in the transferRNA (tRNA) splicing endonuclease subunit 54 gene (TSEN54) (Table 2). Ninety percent of the well-defined $\mathrm{PCH} 2$ cases carried this mutation [37]. This TSEN54 mutation correlated strongly with jitteriness, clonus, dyskinesia and/or dystonia and with flat cerebellar hemispheres on coronal MRI compared to those $\mathrm{PCH}$ cases where no mutation was identified (Figure 1F) [20].

In rare occasions, mutations are found in two of the three other subunit genes of the tRNA splicing endonuclease, TSEN2 and TSEN34 (Table 2) [20,37]. Four patients have been described so far; three with TSEN2 mutations and one with a TSEN34 mutation [20]. These cases have a $\mathrm{PCH} 2$ phenotype, as they exhibited spasticity and/or dyskinesias. Other missense mutations than the p.A307S in TSEN54, have been associated with PCH2 as well (Table 2). Some of these patients with a rare mutation in TSEN54 and the patient with a TSEN34 mutation have relatively mild involvement of pons and cerebellum. On early coronal MRI the cerebellar hemispheres are not completely flat, but fill the posterior fossa almost completely, suggestive of postnatal atrophy rather than hypoplasia [20]. Because only a few patients with TSEN2, TSEN34 and rare TSEN54 missense mutations other than p.A307S have been

Table 2 Pathogenic mutations in PCH.

\begin{tabular}{|c|c|c|c|}
\hline Gene & Nucleotide position & Protein position & Subtype \\
\hline TSEN54 & c.178_215del & p.E60AfsX109 & $\mathrm{PCH} 4$ \\
\hline TSEN54 & c. $285 G>C$ & p.A95A Splice site mutation & $\mathrm{PCH} 4$ \\
\hline TSEN54 & c. $277 \mathrm{~T}>\mathrm{C}$ & p.S93P & $\mathrm{PCH} 4$ \\
\hline TSEN54 & c.371G > T & p.G124V & $\mathrm{PCH} 2$ \\
\hline TSEN54 & c. $370-2 A>G$ & p.G124_Q138del & $\mathrm{PCH} 4$ \\
\hline TSEN54 & c. $468+2 T>C$ & Splice site mutation & $\mathrm{PCH} 5$ \\
\hline TSEN54 & c.736C > T & p.Q246X & $\mathrm{PCH} 4$ \\
\hline TSEN54 & c.919G > T & p.A307s (common) & $\mathrm{PCH} 1, \mathrm{PCH} 2, \mathrm{PCH} 4, \mathrm{PCH} 5$ \\
\hline TSEN54 & c.953delC & p.P318QfsX23 & $\mathrm{PCH} 4$ \\
\hline TSEN54 & c. $1027 \mathrm{C}>\mathrm{T}$ & p.Q343X & $\mathrm{PCH} 4$ \\
\hline TSEN54 & c.1056_1057del & p.R353GfsX81 & $\mathrm{PCH} 4$ \\
\hline TSEN54 & c.1170_1183del & p. V390fsX39 & $\mathrm{PCH} 4$ \\
\hline TSEN54 & c. $1251 A>G$ & p.P417P Splice site mutation & $\mathrm{PCH} 4$ \\
\hline TSEN54 & c. $1430+2 T>A$ & Splice site mutation & $\mathrm{PCH} 4$ \\
\hline TSEN54 & c.1537T > G & p.Y513D & $\mathrm{PCH} 4$ \\
\hline TSEN34 & C. $172 \mathrm{C}>\mathrm{T}$ & p.R58W & $\mathrm{PCH} 2$ \\
\hline TSEN2 & $c .926 \mathrm{~A}>\mathrm{G}$ & p.Y309C & $\mathrm{PCH} 2$ \\
\hline TSEN2 & c.960+1delGTAAG & Splice site mutation & $\mathrm{PCH} 2$ \\
\hline RARS2 & c.35A > G & p.Q12R & $\mathrm{PCH} 1, \mathrm{PCH} 6$ \\
\hline RARS2 & C. $110+5 A>G$ & Splice site mutation & $\mathrm{PCH} 1, \mathrm{PCH} 6$ \\
\hline RARS2 & c. $1024 \mathrm{~A}>\mathrm{G}$ & p.M342V & $\mathrm{PCH} 6$ \\
\hline VRK1 & c. $1072 C>T$ & p.R358X & $\mathrm{PCH} 1$ \\
\hline
\end{tabular}

Note that in PCH4 and PCH5 there is compound heterozygosity for a nonsense or a splice site mutation plus a missense mutation (p.A307S, TSEN54). 
diagnosed thus far, one should be cautious with generalizations about their phenotypes.

Whereas missense mutations in TSEN54 underlie $\mathrm{PCH} 2$, heterozygous missense- plus heterozygous nonsense or splice site mutations in TSEN54 underlie the more severe PCH4 (Table 1 Table 2) [20,27,37]. In one case, three TSEN54 missense mutations were found in $\mathrm{PCH} 4$. This case was homozygous mutant for the common mutation, plus another missense mutation (p.S93P) on one of the alleles, giving rise to a $\mathrm{PCH} 4$ phenotype. Nonsense and splice site mutations in TSEN54 are associated with increased severity of hypoplasia of pons and cerebellum and immaturity of the cerebral cortex with more perinatal symptoms and an earlier lethality than seen in $\mathrm{PCH} 2$.

As in $\mathrm{PCH} 4$, a heterozygous missense mutation (p. A307S) plus a heterozygous splice site mutation (c.468 $+2 \mathrm{~T}>\mathrm{C}$ ) in TSEN54 has been found to be responsible for PCH5 (Table 2) [38]. Although milder, the clinical findings in $\mathrm{PCH} 2$ are similar to $\mathrm{PCH} 4$ and $\mathrm{PCH} 5$. Therefore $\mathrm{PCH} 5, \mathrm{PCH} 4$ and $\mathrm{PCH} 2$ represent a spectrum of clinical manifestations caused by different mutations in the TSEN genes (Table 1). It is still unclear whether $\mathrm{PCH} 1$ is part of this spectrum too, as the common mutation in TSEN54 was identified in one case from a family with three siblings with a PCH1 phenotype [40]. DNA was only available in one of the three siblings. Post-mortem examination revealed neuronal cell loss of the anterior horns of the cervical cord [40]. PCH1 seems to be more heterogeneous than $\mathrm{PCH} 2 / \mathrm{PCH} 4$ and several genes are already involved in the minority of the $\mathrm{PCH} 1$ cases.

Reliable estimations of the incidence of the common/ p.A307S mutation (TSEN54) are difficult to obtain. Although $\mathrm{PCH} 2$ with this underlying mutation is the most common form of $\mathrm{PCH}$, it is still a rare disease and clusters in isolated communities. In the Dutch and German population the carrier frequency of the common mutation is 0.004 [37]. With 184915 newborns in the Netherlands in the year 2009 one would expect 3 affected children per annum [41]. However, since the p. A307S mutation occurs in closed communities, where consanguinity occurs, probably more affected children are born per year, than one would expect based on carrier frequency in unrelated Caucasian individuals. Therefore preconceptional testing with prenatal diagnosis for this disease in selected regions is advised.

\section{RARS2-related PCH}

Following homozygosity mapping in the first published PCH6 family, a homozygous intronic splice site mutation $(c \cdot 110+5 \mathrm{~A}>\mathrm{G})$ was found in the gene for the nuclear encoded mitochondrial arginyl-tRNA synthetase (RARS2) (Table 2) [12]. A second PCH6 case with additional progressive encephalopathy and edema was compound heterozygote for RARS2 missense mutations (Table 2) [39].

Mutations in RARS2 were identified in one case with a $\mathrm{PCH} 1$ phenotype [20]. Although this case had high CSF lactate levels, which is normally not reported in PCH1, post-mortem examination revealed a neuropathological profile that fits a $\mathrm{PCH} 1$ phenotype with loss of spinal anterior horn neurons.

\section{Other genes and loci involved in $\mathrm{PCH}$}

Nonsense mutations in the Vaccinia Related Kinase1 gene (VRK1) were reported to be associated with pontocerebellar hypoplasia plus SMA in one atypical PCH1 family of Ashkenazi Jewish origin [42]. Despite the severe microcephaly at birth (fronto-occipital circumference -3SD and -6SD), the three affected children were mildly delayed in their developmental milestones. The proband was e.g. able to walk at the age of 3 years; however she became wheelchair bound later in life and eventually died at the age of 11 years. Cognitive impairment was stated as mild mental retardation, whereas in typical $\mathrm{PCH} 1$ cases there is severe mental retardation and no developmental milestones will be achieved [7,10,21-25]. Up to now no other cases with VRK1 mutations have been reported.

Mutations or deletions in the survival motor neuron gene (SMN1) cause SMA. In PCH1 linkage to the SMN genes has been excluded; although the motor neuron loss observed in PCH1 is morphologically similar to the motor neuron loss in SMA $[43,44]$. There is no locus for the majority of the PCH1 cases and no other genes have been linked to $\mathrm{PCH} 1$ yet, with the exception of rare cases with TSEN54, RARS2 and VRK1 mutations (Table 2). Fifteen families with a $\mathrm{PCH} 1$ phenotype have been published thus far; only in 3 families mutations were identified $[6,7,10,20-25,34,40,42,44-51]$. Further research on these and other candidate genes in PCH1 is necessary to identify mutations involved in the remaining majority of the $\mathrm{PCH} 1$ cases.

Linkage on chromosome $7 \mathrm{q}$ was found in two of the three families with $\mathrm{PCH} 3$, but no causative gene has been found [30,31]. Unfortunately no linkage analysis was performed in the most recently published case with PCH3 [32].

There is no locus yet for $\mathrm{PCH} 7$, however sequencing of the coding regions in TSEN54, TSEN34, TSEN2, TSEN15 and RARS2 yielded no mutations. FISH analysis of $S R Y$ and Xq12 and a CGH-array appeared to be normal, as well as ARX expansion analysis [13].

\section{Management and Treatment}

There is no cure for PCH: Management is only symptomatic and includes nutritional support by percutaneous endoscopic gastrostomy (PEG feeding), treatment of 
dystonia, dyskinesias and seizures. Sometimes respiratory support is provided. The chorea in $\mathrm{PCH} 2$ is difficult to treat, but physiotherapy may ease cases with severe dystonia or spasticity. Levodopa treatment appeared beneficial in some cases [52].

Life-threatening complications of PCH are cot death, sleep apnea and malignant hyperthermia with rhabdomyolysis with extreme elevation of plasma creatine kinase. Sleep apnea can be detected by sleep monitoring. Malignant hyperthermia should be prevented by sufficient hydration and monitoring especially during periods of infection [26].

Other diseases with (ponto)cerebellar hypoplasia

There are several other diseases that one may consider when a patient presents with pontocerebellar hypoplasia, see also Table 3 for an indication.
Genetic diseases with cerebellar hypoplasia and/or atrophy and variable cerebral cortical atrophy

Recently a new PCH-like phenotype has been described: Progressive Cerebello-Cereberal Atrophy (PCCA). Patients with PCCA have postnatal atrophy of the cerebellar hemispheres, which is not typical for $\mathrm{PCH}$, but some $\mathrm{PCH}$ patients do have this feature [20,30]. Patients with PCCA have progressive microcephaly, severe spasticity, mental retardation and in some cases seizures. Sequential brain MRI of patients shows the progressive nature of the cerebellar and cerebral atrophy. Missense mutations in the $O$-phosphoseryl-tRNA selenocysteine tRNA synthase gene (SEPSECS) are associated with this disease (Table 3) [53].

In infantile cerebral and cerebellar atrophy (ICCA) there is also cerebellar volume loss with psychomotor retardation, seizures, jitteriness, clonus, severe spasticity,

Table 3 Differential diagnostic options for $\mathrm{PCH}$.

\begin{tabular}{|c|c|c|c|c|}
\hline Differential diagnosis & Cerebellar Hypoplasia plus: & Gene(s) & Pathways involved & $\begin{array}{l}\text { Key } \\
\text { references }\end{array}$ \\
\hline \multicolumn{5}{|c|}{ Genetic diseases with cerebellar hypoplasia and/or atrophy and variable cerebral cortical atrophy } \\
\hline PCCA & $\begin{array}{l}\text { Progressive Cerebello-cerebral atrophy, } \\
\text { progressive microcephaly, spasticity, seizures, } \\
\text { mental retardation and seizures. }\end{array}$ & $\begin{array}{l}\text { Missense } \\
\text { mutations in } \\
\text { SEPSECS. }\end{array}$ & Selenocysteine synthesis & {$[53]$} \\
\hline ICCA & $\begin{array}{l}\text { Severe atrophy of cerebrum and cerebellum. } \\
\text { Psychomotor retardation, clonus, seizures, } \\
\text { spasticity, progressive microcephaly. }\end{array}$ & $\begin{array}{l}\text { Missense } \\
\text { mutations in } \\
\text { MED17 }\end{array}$ & Transcripition initiation & {$[54]$} \\
\hline CDG type $1 \mathrm{~A}$ and $1 \mathrm{D}$ & $\begin{array}{l}\text { Hypotonia, ataxia, developmental delay, failure } \\
\text { to thrive, microcephaly. }\end{array}$ & $\begin{array}{l}\text { PMM2 } \\
\text { (type1a), ALG3 } \\
\text { (type 1d) }\end{array}$ & Glycoprotein biosynthesis & {$[55,56]$} \\
\hline $\begin{array}{l}\text { Phosphoserine aminotransferase } \\
\text { deficiency }\end{array}$ & $\begin{array}{l}\text { Low CSF concentrations of serine and glycine, } \\
\text { seizures, progressive microcephaly, hypertonia } \\
\text { and psychomotor retardation. White matter } \\
\text { immaturity and cerebral atrophy. }\end{array}$ & PSAT & Serine biosynthesis & {$[59]$} \\
\hline $\begin{array}{l}\text { Different congenital mitochondrial } \\
\text { disorders }\end{array}$ & $\begin{array}{l}\text { Respiratory chain deficiencies plus several other } \\
\text { abnormalities. }\end{array}$ & - & $\mathrm{n} / \mathrm{a}$ & {$[60]$} \\
\hline PEHO-syndrome & $\begin{array}{l}\text { Progressive cerebellar atrophy, progressive } \\
\text { encephalopathy, hypsarrythmie, edema and } \\
\text { optic atrophy. }\end{array}$ & Unknown & Unknown & {$[62,63]$} \\
\hline \multicolumn{5}{|c|}{ Genetic diseases with cerebellar hypoplasia plus neocortical dysplasia } \\
\hline $\begin{array}{l}\text { Dystroglanopathies: Walker- } \\
\text { Warburg syndrome, MEB-disease, } \\
\text { Fukuyama }\end{array}$ & $\begin{array}{l}\text { Neocortical dysplasia. Mental retardation, eye } \\
\text { abnormalities, seizures, impaired motor control. }\end{array}$ & $\begin{array}{l}\text { FKRP, LARGE, } \\
\text { POMGNT1, } \\
\text { POMT1, } \\
\text { POMT2, FKTN }\end{array}$ & Dystroglycan synthesis & {$[64,65]$} \\
\hline Lissencephaly & Lissencephaly phenotype. & RELN & Neuronal migration & {$[67]$} \\
\hline $\begin{array}{l}\text { X-linked brain malformation } \\
\text { phenotype with microcephaly and } \\
\text { hypoplasia of the brainstem and } \\
\text { cerebellum }\end{array}$ & $\begin{array}{l}\text { Microcephaly, optic atrophy, sensorineural } \\
\text { hearing loss, simplified gyri, developmental } \\
\text { delay. }\end{array}$ & CASK & $\begin{array}{l}\text { Neuronal migration; Part of } \\
\text { MAGUK protein family, involved } \\
\text { in signaling in both, pre- and } \\
\text { post-synapses. }\end{array}$ & {$[66]$} \\
\hline $\begin{array}{l}\text { Congenital fibrosis of the } \\
\text { extraocular muscles } 3 \text { with } \\
\text { extraocular involvement }\end{array}$ & $\begin{array}{l}\text { Ocular motility disorder, facial weakness, axonal } \\
\text { peripheral neuropathy, delayed development, } \\
\text { neocortical dysplasia and other neuronal } \\
\text { migration disorders. }\end{array}$ & TUBB3 & Neuronal migration & {$[68,69]$} \\
\hline \multicolumn{5}{|l|}{ Acquired cerebellar hypoplasia } \\
\hline Extreme prematurity (<32 weeks) & Extreme prematurity. & $\mathrm{n} / \mathrm{a}$ & $\mathrm{n} / \mathrm{a}$ & {$[70]$} \\
\hline
\end{tabular}


visual problems, hypertonia and progressive postnatal microcephaly. Brain MRI shows severe atrophy of cerebrum and cerebellum (Table 3) [54].

Certain subtypes of the congenital disorders of glycosylation (CDG) disorders manifest with cerebellar hypoplasia as well. CDG-1a patients have generalized hypotonia, developmental delay, swallowing problems, failure to thrive and cerebellar hypoplasia, next to variable external dysmorphia and hematologic problems [55]. Cerebellar hypoplasia is also present in patients with CDG-1d, a rare form of CDG (Table 3) [56-58].

Phosphoserine aminotransferase deficiency is associated with low CSF concentrations of serine and glycine. Clinically patients exhibit seizures, progressive microcephaly, hypertonia and psychomotor retardation. MRI shows cerebral atrophy, poor white matter development and vermal hypoplasia. The authors did not mention the size and morphology of the cerebellar hemispheres (Table 3) [59]. Also in various pediatric mitochondrial disorders predominant cerebellar volume loss is relatively common, together with respiratory chain deficiencies (Table 3) [60,61]. Progressive cerebellar atrophy is commonly found in patients with PEHOsyndrome (Table 3) $[62,63]$.

\section{Genetic diseases with cerebellar hypoplasia plus neocortical dysplasia}

Dystroglycanopathies cause neocortical dysplasia and variable pontocerebellar hypoplasia and microcephaly or hydrocephalus (Table 3) [64,65]. An X-linked brain malformation phenotype with a moderately simplified gyral pattern and mild cortical dysplasia, only visible on autopsy is due to mutations in the calcium/calmodulin dependent serine protein kinase gene $(C A S K)$. It can manifests with microcephaly, optic atrophy, sensorineural hearing loss and pontocerebellar hypoplasia (Table 3) [66]. Other diseases with cerebellar hypoplasia and additional neocortical dysplasia but easier to differentiate from $\mathrm{PCH}$, are lissencephaly with agyria or very wide gyria and congenital fibrosis of the extraocular muscles type 3 (CFEOM3) with extraocular involvement like neocortical dysplasia and neuronal migration defects (Table 3) [67-69].

\section{Acquired cerebellar hypoplasia}

Extreme prematurity (<32 weeks) in infants can also lead to cerebellar hypoplasia, due to disruption of normal brain development. One should be aware of this when a prematurely born neonate presents with these features (Table 3) [70,71].

\section{Pathogenesis}

\section{The function of the tRNA splicing endonuclease}

The tRNA splicing endonuclease (TSEN) complex is mutated in the majority of the $\mathrm{PCH}$ cases. The endonuclease complex is encoded by four different TSEN genes
(TSEN2, 15, 34, 54) and consists of four protein subunits. Together they form one heterotetramic enzyme, consisting of two catalytic subunits (TSEN2 and TSEN34) and two structural subunits (TSEN54 and TSEN15) [72-74]. In mammals, maturation of tRNA necessitates removal of the 5' leader and 3' trailer sequences, addition of a CCA tail and various modifications [75]. Six percent of the human tRNA genes are intron-containing; this intron is not removed by the conventional splicing machinery, but by the TSEN complex. Only these intron-containing tRNAs require the TSEN complex for excising the tRNA into two halves; one 5'tRNA half with a 2'-3' cyclic phosphate at the cleavage site and a $3^{\prime}$ tRNA half with a $5^{\prime} \mathrm{OH}$-group at the other cleavage site (Figure 2A). The individual halves of the tRNA are ligated together again. Mature tRNAs are essential for translation of messengerRNA (mRNA) into proteins, as they transfer the correct amino acid to the ribosome to incorporate these amino acids at the growing peptide chain. Each amino acid has its own cognate tRNA and each tRNA has an anticodon sequence that can interact to the corresponding codon on mRNA sequence. In humans there are 506 different tRNA genes, meaning that there are more tRNA genes than codons. For certain tRNA species the majority of the tRNA genes are intron-containing: For example, 13 of the 14 tRNA-Tyr (GTA) genes contain an intron (Table 4). For other tRNAs there are no intron-containing tRNA genes at all: For example all tRNA-Gly (GCC, CCC, TCC) genes are not intron-containing. For further information on intron-containing and intronless tRNA genes, see [76].

The TSEN complex is not only involved in tRNA splicing, it is also involved in mRNA 3'end formation. Knockdown of TSEN2 results in impaired mRNA 3'end formation of two housekeeping transcripts GAPDH and EF1A mRNA in HEK293 cells [73]. Furthermore the TSEN complex interacts with a lot of factors associated with the mRNA 3'end processing machinery [73,77].

In 2007, the human cleavage and polyadenylation factor I subunit (hClp1) was identified as siRNA kinase. hClp1 is a binding partner of the TSEN complex and its kinase activity is also active on 3'tRNA halves, furthermore hClp1 participates in mRNA 3'end formation [78-80]. It seems that multiple enzymes involved in RNA processing assemble into a molecular equivalent of a 'Swiss Army Knife', creating a complex that can cleave and process several different RNA species [79].

\section{The TSEN complex and PCH}

In vitro studies of the TSEN complex In 2006 the yeast Sen complex was purified and different mutations in the complex were introduced; this showed that certain mutations abolished tRNA splicing activity whereas others do not affect tRNA splicing at all [74]. The 

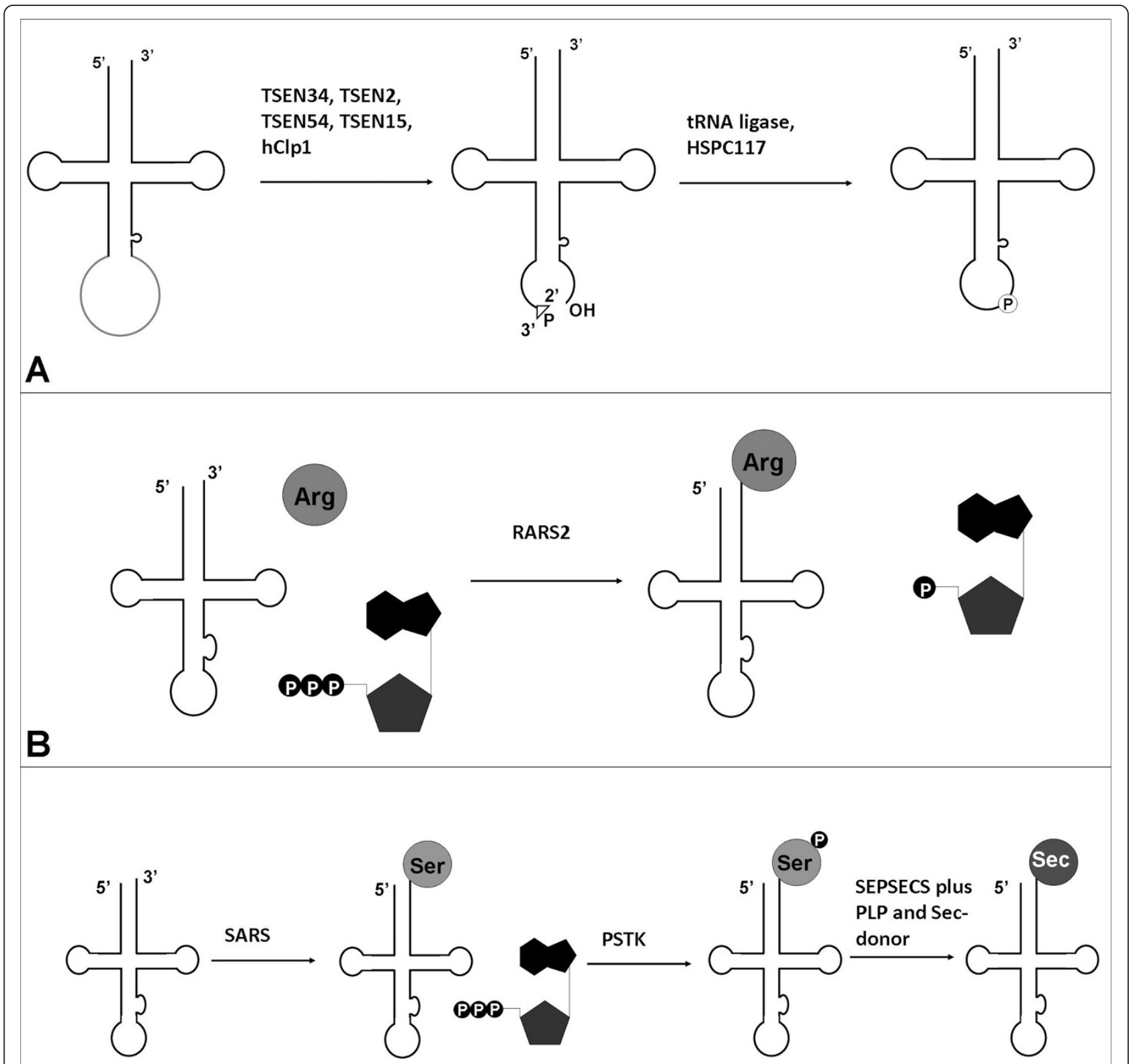

C

Figure 2 Different RNA processing events in mammals. 2A: Eukaryotic splicing pathway of tRNA splicing in mammals. The TSEN complex is involved in the maturation of premature tRNAs and excises the tRNA into two halves; one 5'tRNA half with a 2'-3' cyclic phosphate at one exonend and a $3^{\prime}$ tRNA half with a $5^{\prime} \mathrm{OH}$-group at the other exon-end. The final processing of tRNA maturation involves either direct ligation of the two tRNA halves by ligation through the Archaea-like pathway (by HSPC117, depicted) or indirect ligation through the yeast-like pathway (not depicted) [104]. Adapted from Calvin et al. [105]. 2B: tRNA aminoacylation in mammals. RARS2 can bind to its cognate amino acid in an ATP dependent matter. This complex of ATP, RARS2 and arginine binds to the mt-tRNA-Arg and arginine will be transferred to its tRNA. Adapted from Antonellis et al. [83]. 2C: Selenocysteine synthesis. Serine (Ser) is aminoacylated to tRNA-Sec by a seryl-tRNA synthetase (SARS). This SertRNA-Sec complex is then converted by a kinase to a Sep-tRNA-Sec complex. In the presence of the cofactor pyridoxal phosphate (PLP) and the selenium donor selenophosphate (Se-donor) the SEPSECS enzyme converts the Sep-tRNA-Sec to Sec-tRNA-Sec. Adapted from Allmang et al. [87]. 
Table 4 Overview of the number of human tRNA genes with an intron and the remaining corresponding tRNAs without an intron.

\begin{tabular}{lll}
\hline $\begin{array}{l}\text { Human tRNA } \\
\text { species with } \\
\begin{array}{c}\text { an intron } \\
\text { (anticodon) }\end{array}\end{array}$ & $\begin{array}{c}\text { Number of } \\
\text { human tRNA } \\
\text { genes with an } \\
\text { intron }\end{array}$ & $\begin{array}{c}\text { Number of the remaining } \\
\text { human tRNA genes } \\
\text { without an intron (same } \\
\text { anticodon) }\end{array}$ \\
\hline Pro - AGG & 1 & 9 \\
Arg - TCT & 5 & 1 \\
Leu - CAA & 5 & 2 \\
Ile - TAT & 5 & 0 \\
Tyr - ATA & 1 & 0 \\
Tyr - GTA & 13 & 1 \\
Cys - ACA & 1 & 0 \\
Trp - CCA & 1 & 8 \\
\hline
\end{tabular}

Adapted from the Genomic tRNA database [76].

authors also show that the same mutation can have a different effect on tRNA splicing, depending on the different tRNA: E.g. tRNA-Phe is usually not as strongly affected by mutations as tRNA-Tyr. Certain tRNA transcripts are perhaps spliced more readily than other tRNA transcripts [74]. This illustrates that it is difficult to predict how mutations in the TSEN complex will affect tRNA splicing in $\mathrm{PCH}$ patients. It is likely that tRNA splicing activity in patients is reduced, and not completely abolished as no patients to date have been described with two nonsense mutations in one of the TSEN subunits; this would abrogate tRNA splicing completely and lead to deprivation of certain amino acids, which would be non-compatible with life.

Generally, PCH4 patients have a null allele and a missense mutation in TSEN54 and are therefore more severely affected than $\mathrm{PCH} 2$ patients who carry two missense mutations in TSEN54. This genotype-phenotype correlation suggests that loss of TSEN function is the underlying disease mechanism in $\mathrm{PCH} 2$ and $\mathrm{PCH} 4$. One could hypothesize that a defective TSEN complex would lead to insufficient tRNA splicing, mainly affecting intron-rich tRNA genes, like tRNA-Tyr (Table 4). However Northern blot analysis of tRNA-Tyr from fibroblasts of three patients homozygous for the common mutation in TSEN54 did not show unspliced products. No significant difference was found in mature tRNA-Tyr levels in fibroblasts of patients and controls either [37]. To summarize, there is no evidence for a tRNA maturation defect in TSEN-mutated fibroblasts. Neuronal cells derived from patients would be a better substrate for tRNA maturation analysis, but unfortunately brain material is scarce and usually severely affected at the time of death. Induced pluripotent stem cell (iPS) technology might circumvent this problem, but even when patient fibroblasts can be converted to neuronal cells, there is no guarantee that these cells will show a phenotype. After all, not all neurons in a $\mathrm{PCH}$ case are affected.

It remains possible that other unknown (cell type specific) functions of the TSEN complex may play a role in the disease pathogenesis of $\mathrm{PCH}$ cases.

Zebrafish models of TSEN related PCH Recently we established a zebrafish model for PCH. Knockdown of tsen 54 by antisense morpholino injections in zebrafish embryos resulted in abnormalities in the mid-hindbrain and a developmental delay. The zebrafish embryos showed head hypoplasia and loss of structural integrity in the brain. The loss of structural definition in the brain is not due to a patterning defect, since fibroblast growth factor $8(F g f 8)$ and orthodenticle homeobox 2 (Otx2), two developmental markers, were expressed in the correct regions. Instead the developing zebrafish embryo's showed increased levels of cell death, bearing comparisons to the neurodegeneration observed in $\mathrm{PCH}$. This neurodegenerative phenotype is partially rescued by co-injecting human TSEN54 mRNA in zebrafish embryos [81].

Expression analysis of tsen 54 in zebrafish shows a ubiquitous expression pattern, but higher expression in brain, primarily in the telencephalon and mid-hindbrain boundary. This is in line with the expression of human TSEN54 mRNA at eight weeks of gestation, in which high expression in the developing telencephalon and metencephalon is observed [81]. The human cerebellum begins its development at six weeks of gestation and continues growing into the postnatal period [82]. With careful monitoring in $\mathrm{PCH} 4 / \mathrm{PCH} 5$ cases, one can already measure a decline in transverse cerebellar diameter at 16 weeks of gestation, indicating a very early onset of the neurodegeneration [11].

Antisense morpholino effects diminish after a few days post-injection. Therefore we also developed a stable tsen 54 knockout zebrafish carrying a premature stop codon. When bred to homozygosity these zebrafish mutants were viable at 9 days post fertilization ( $\mathrm{dpf}$ ). The absence of a major brain phenotype and survival up to 9 -dpf may be explained by the presence of maternal tsen54 during embryogenesis [81]. Redundancy of the protein in zebrafish is not likely, as eventually these mutant zebrafish die after 9 days.

\section{RARS2 and $P C H$}

RARS2, mutated in PCH6 and PCH1, is one of the 36 human tRNA synthetases. By the usage of ATP, the tRNA synthetase binds to its cognate amino acid. This complex of ATP, tRNA synthetase and amino acid, binds to the appropriate tRNA whereto the amino acid will be transferred (Figure 2B) [83]. RARS2 is involved in the aminoacylation of arginine (Arg) to its mitochondrial- tRNA-Arg. In RARS2 mutated (c. $110+5 A>G)$ fibroblasts, a reduction in the amount of the mt- tRNA- 
Arg was observed. Despite this reduction, the residual mt- tRNA-Arg transcript was almost completely acylated, suggesting that uncharged mt-tRNA-Arg transcripts are unstable [12]. Morpholino-directed knockdown of rars 2 in zebrafish resulted in a similar neurodegenerative phenotype as tsen 54 knockdown, suggesting the same pathogenesis for $\mathrm{PCH} 2 / 4$ and PCH6, although it is still not understood how RARS2 is involved in the development of the pons and cerebellum [81].

Alternative functions of RARS2 compromising the same biological pathway as the TSEN complex could also be the underlying mechanism in $\mathrm{PCH}[73,78,81]$. For some of the tRNA synthetases alternative functions are known in processes like conventional splicing, apoptosis, viral assembly, regulation of transcriptional and translational processes and angiogenic signaling [83-85].

\section{SEPSECS and PCCA}

Mutations in SEPSECS are associated with PCCA (progressive cerebello-cerebral atrophy). The SEPSECS enzyme (Figure $2 \mathrm{C}$ ) is involved in the final step of the selenocysteine ( $\mathrm{Sec}$ ) synthesis [86,87]. Selenocysteine lacks its own tRNA synthetase and in contrast to the other amino acids selenocysteine is synthesized on its cognate tRNA. The codon for selenocysteine is UGA, normally encoding for translation termination, however depending on the flanking sequences of the UGA, this codon is recoded for a selenocysteine. Prior to selenocysteine synthesis, serine (Ser) is aminoacylated to tRNA-Sec by a seryl-tRNA synthetase; this Ser-tRNASec complex is then converted by a kinase to a SeptRNA-Sec complex. As a final step SEPSECS converts the Sep-tRNA-Sec to Sec-tRNA-Sec. It is not likely that SEPSECS missense mutations (p.A239T, p.Y334K) completely abolish its function, as deprivation of selenocysteins is associated with lethality in mice [88].

\section{Discussion}

The identification of mutations in genes involved in transcription and translation in neurological disorders shows that these processes are important in (developing) neurons [83,89-94]. The TSEN complex, RARS2 and SEPSECS proteins, all share involvement in essential processes in protein synthesis and mutations in the corresponding genes all lead to a severe phenotype of pontocerebellar hypoplasia, often in combination with cortical involvement. One explanation could be that developing neuronal tissue is sensitive to dysregulation of protein synthesis [83,92-94]. This hypothesis is supported by mice with a homozygous missense mutation in the alanyl-tRNA synthetase gene (AARS). This mouse has increased levels of mischarged tRNAs which lead to intracellular accumulation of misfolded proteins in neurons, this induces the unfolded protein response (UPR) and these mice develop a neurodegenerative phenotype, with Purkinje cell death and subsequent ataxia [95]. However UPR activation has not been detected in postmortem brain of $\mathrm{PCH} 2$ patients carrying a TSEN mutation, but one can argue that UPR activation is an early event in the pathogenesis of $\mathrm{PCH}$ and that postmortem studies do not capture this event [19].

On the other hand it is possible that there is a time frame during embryogenesis in which there is an extra high demand for protein synthesis in neuronal tissue in the early post-migratory stage. Human brain tissue expresses relatively high overall levels of nuclear and mitochondrial encoded tRNAs, which might be due to higher levels of translation in the CNS compared to other tissue [96]. Moreover, malnutrition in rats during the prenatal period has severe consequences for brain development and the cerebellum in particular [97]. Protein malnutrition both prenatally and postnatally, results in reduced brain weight, thinner cerebral and cerebellar cortices, reduced numbers of neurons, deficient myelination and reduced dendritic spines of cortical neurons $[98,99]$. Therefore it is very likely that nutrients and proteins are highly essential for normal brain development.

Why mutations in other genes involved in protein synthesis lead to completely different phenotypes remains unclear. For example, mutations in other genes involved in tRNA charging like KARS, YARS and GARS lead to different types of Charcot-Marie-Tooth neuropathy $[83,100,101]$. Mitochondrial aspartyl-tRNA synthetase (DARS2) mutations cause leukoencephalopathy with brain stem and spinal cord involvement and lactate elevation (LBSL). Patients with LBSL have profound white matter abnormalities in their cerebrum, pons and spinal cord. There are some similarities between LBSL and $\mathrm{PCH}$, like cerebellar involvement and spasticity, but the differences are more evident. Patients have slowly progressive cerebellar ataxia, dorsal column dysfunction, occasionally a mild cognitive decline and the age of onset is usually during childhood or even later. It is unclear how mutations in DARS2 lead to LBSL [89].

Not all mutations in tRNA synthetase genes result in a neurological phenotype. Missense mutations in the mitochondrial Seryl-tRNA Synthetase gene (SARS2) give rise to a multi-organ disease with Hyperuricemia, Pulmonary Hypertension, Renal Failure and Alkalosis (HUPRA-syndrome). Although there is failure to thrive and a global developmental delay, patients exhibit no neurological symptoms and brain ultrasound was reported to be normal [102]. Compound heterozygote mutations in mitochondrial histidyl-tRNA synthetase gene (HARS2) were found in one family with ovarian dysgenesis and progressive sensorineural hearing loss (Perrault syndrome) [103]. 
In summary, the most likely explanation for the neurological phenotype in the disorders described above is that maturing neurons are more vulnerable for defects in protein synthesis than other tissues, but this does not explain the difference between disease presentation shared by mutations of TSEN, RARS 2 and SEPSECS, in which the cerebellum appears to be preferentially affected and other diseases (KARS, YARS, GARS, $S A R S 2)$, with a different disease presentation.

\section{Conclusions and Outlook}

During the last decade many genes involved in protein synthesis have been associated with different neurological diseases. Several genes of PCH subtypes have been described, in view of the shared function in tRNA processing, a defect in protein synthesis seems the most likely pathomechanism in $\mathrm{PCH}$. Hopefully identification of new genes in $\mathrm{PCH}$ subtypes will provide further insight and lead us to a common disease pathway. Also further research on TSEN and/or RARS2 function in $\mathrm{PCH}$ models is necessary to elucidate the question why solely the brain, and specifically the cerebellum and pons are affected in $\mathrm{PCH}$.

\section{Acknowledgements \& Funding}

We thank Dr. Paul Kasher for careful reading of the manuscript and helpful discussions. Financial support was kindly provided by the Hersenstichting Nederland KS2009(1)-81. Y.N. is supported by an AMC graduate school fellowship.

\section{Author details}

'Department of Genome Analysis, Academic Medical Center, University of Amsterdam, Meibergdreef 9, 1105 AZ Amsterdam, The Netherlands. 'Division of Pediatric Neurology, Emma's Childrens Hospital, Academic Medical Center, University of Amsterdam, Meibergdreef 9, 1105 AZ Amsterdam, The Netherlands.

\section{Authors' contributions}

All authors made substantial contributions and have given final approval to the version being published.

\section{Competing interests}

The authors declare that they have no competing interests.

Received: 26 April 2011 Accepted: 12 July 2011 Published: 12 July 2011

\section{References}

1. Brun R: Zur Kenntnis der Bildungsfehler des Kleinhirns. Epikritische Bemerkungen zur Entwicklungspathologie, Morphologie und Klinik der umschriebenen Entwicklungshemmungen des Neozerebellums. Schweiz Arch Neurol Psychiatr 1917, 1:48-105.

2. Brouwer B: Hypoplasia ponto-neocerebellaris. Psychiatr Neurol (Amsterdam) 1924, 6:461-469.

3. Koster S: Two cases of hypoplasia ponto-neocerebellaris. Acta Psychiatr (Københ) 1926, 1:47-76.

4. Krause F: Über einen Bildungsfehler des Kleinhirns und einige faseranatomische Beziehungen des Organs. Zeitschrift der Gesammten Neurologie und Psychiatrie 1928, 119:788-815.

5. Biemond A: Hypoplasia ponto-neocerebellaris, with malformation of the dentate nucleus. Folia Psychiatr Neurol Neurochir Neerl 1955, 58:2-7.

6. Norman RM: Cerebellar hypoplasia in Werdnig-Hoffmann disease. Arch Dis Child 1961, 36:96-101.
7. Goutieres F, Aicardi J, Farkas E: Anterior horn cell disease associated with pontocerebellar hypoplasia in infants. J Neurol Neurosurg Psychiatry 1977, 40:370-378.

8. Peiffer J, Pfeiffer RA: Hypoplasia ponto-neocerebellaris. J Neurol 1977, 215:241-251.

9. Barth PG, Vrensen GF, Uylings HB, Oorthuys JW, Stam FC: Inherited syndrome of microcephaly, dyskinesia and pontocerebellar hypoplasia: a systemic atrophy with early onset. J Neurol Sci 1990, 97:25-42.

10. Barth PG: Pontocerebellar hypoplasias. An overview of a group of inherited neurodegenerative disorders with fetal onset. Brain Dev 1993, 15:411-422.

11. Patel MS, Becker LE, Toi A, Armstrong DL, Chitayat D: Severe, fetal-onset form of olivopontocerebellar hypoplasia in three sibs: PCH type 5? Am J Med Genet A 2006, 140:594-603.

12. Edvardson S, Shaag A, Kolesnikova O, Gomori JM, Tarassov I, Einbinder T, Saada A, Elpeleg O: Deleterious mutation in the mitochondrial arginyltransfer RNA synthetase gene is associated with pontocerebellar hypoplasia. Am J Hum Genet 2007, 81:857-862.

13. Anderson C, Davies JH, Lamont L, Foulds N: Early Pontocerebellar Hypoplasia with Vanishing Testes: A New Syndrome? Am J Med Genet Part A 2011, 155:667-672.

14. Albrecht S, Schneider MC, Belmont J, Armstrong DL: Fatal infantile encephalopathy with olivopontocerebellar hypoplasia and micrencephaly. Report of three siblings. Acta Neuropathol 1993, 85:394-399.

15. Barth PG, Blennow G, Lenard HG, Begeer JH, van der Kley JM, Hanefeld $F$, Peters AC, Valk J: The syndrome of autosomal recessive pontocerebellar hypoplasia, microcephaly, and extrapyramidal dyskinesia (pontocerebellar hypoplasia type 2): compiled data from 10 pedigrees. Neurology 1995, 45:311-317.

16. Chaves-Vischer V, Pizzolato GP, Hanquinet S, Maret A, Bottani A, Haenggeli CA: Early fatal pontocerebellar hypoplasia in premature twin sisters. Eur J Paediatr Neurol 2000, 4:171-176.

17. Goasdoue P, Rodriguez D, Moutard ML, Robain O, Lalande G, Adamsbaum C: Pontoneocerebellar hypoplasia: definition of MR features. Pediatr Radiol 2001, 31:613-618.

18. Steinlin M, Klein A, Haas-Lude K, Zafeiriou D, Strozzi S, Muller T, GubserMercati D, Schmitt MT, Krageloh-Mann I, Boltshauser E: Pontocerebellar hypoplasia type 2: variability in clinical and imaging findings. Eur J Paediatr Neurol 2007, 11:146-152.

19. Barth PG, Aronica E, de Vries L, Nikkels PG, Scheper W, Hoozemans JJ, PollThe BT, Troost D: Pontocerebellar hypoplasia type 2: a neuropathological update. Acta Neuropathol 2007, 114:373-386.

20. Namavar Y, Barth PG, Kasher PR, van Ruissen F, Brockmann K, Bernert G, Writzl K, Ventura K, Cheng EY, Ferriero DM, et al: Clinical, neuroradiological and genetic findings in pontocerebellar hypoplasia. Brain 2011, 134:143-156

21. Rudnik-Schoneborn S, Sztriha L, Aithala GR, Houge G, Laegreid LM, Seeger J, Huppke M, Wirth B, Zerres K: Extended phenotype of pontocerebellar hypoplasia with infantile spinal muscular atrophy. Am $J$ Med Genet A 2003, 117A:10-17.

22. Gorgen-Pauly U, Sperner J, Reiss I, Gehl HB, Reusche E: Familial pontocerebellar hypoplasia type I with anterior horn cell disease. Eur $\rfloor$ Paediatr Neurol 1999, 3:33-38.

23. Ryan MM, Cooke-Yarborough CM, Procopis PG, Ouvrier RA: Anterior horn cell disease and olivopontocerebellar hypoplasia. Pediatr Neurol 2000, 23:180-184.

24. Szabo N, Szabo H, Hortobagyi T, Turi S, Sztriha L: Pontocerebellar hypoplasia type 1. Pediatr Neurol 2008, 39:286-288.

25. Okanishi T, Mori Y, Shirai K, Kobayashi S, Nakashima H, Kibe T, Yokochi K, Togari H, Nonaka I: Delayed gyration with pontocerebellar hypoplasia type 1. Brain Dev 2010, 32:258-262.

26. Barth $P G$, Ryan MM, Webster RI, Aronica E, Kan A, Ramkema M, Jardine $P$, Poll-The BT: Rhabdomyolysis in pontocerebellar hypoplasia type 2 ( $\mathrm{PCH}-$ 2). Neuromuscul Disord 2008, 18:52-58.

27. Cassandrini D, Biancheri R, Tessa A, Di RM, Di CM, Bruno C, Denora PS, Sartori S, Rossi A, Nozza P, et al: Pontocerebellar hypoplasia: clinical, pathologic, and genetic studies. Neurology 2010, 75:1459-1464.

28. Valayannopoulos V, Michot C, Rodriguez D, Hubert L, Saillour Y, Labrune P, de LJ, Brunelle F, Amiel J, Lyonnet S, et al: Mutations of TSEN and CASK 
genes are prevalent in pontocerebellar hypoplasias type 2 and 4. Brain 2011.

29. Graham JM Jr, Spencer AH, Grinberg I, Niesen CE, Platt LD, Maya M, Namavar $Y$, Baas F, Dobyns WB: Molecular and neuroimaging findings in pontocerebellar hypoplasia type $2(\mathrm{PCH} 2)$ : is prenatal diagnosis possible? Am J Med Genet A 2010, 152A:2268-2276.

30. Rajab A, Mochida GH, Hill A, Ganesh V, Bodell A, Riaz A, Grant PE, Shugart $Y$, Walsh CA: A novel form of pontocerebellar hypoplasia maps to chromosome 7q11-21. Neurology 2003, 60:1664-1667.

31. Durmaz B, Wollnik B, Cogulu O, Li Y, Tekgul H, Hazan F, Ozkinay F: Pontocerebellar hypoplasia type III (CLAM): Extended phenotype and novel molecular findings. J Neurol 2009, 256:416-419.

32. Jacob FD, Hasal S, Goez HR: Pontocerebellar hypoplasia type 3 with severe vitamin A deficiency. Pediatr Neurol 2011, 44:147-149.

33. Kawagoe $T$, Jacob H: Neocerebellar hypoplasia with systemic combined olivo-ponto-dentatal degeneration in a 9-day-old baby: contribution to the problem of relations between malformation and systemic degeneration in early life. Clin Neuropathol 1986, 5:203-208.

34. Moerman P, Barth PG: Olivo-ponto-cerebellar atrophy with muscular atrophy, joint contractures and pulmonary hypoplasia of prenatal onset. Virchows Arch A Pathol Anat Histopathol 1987, 410:339-345.

35. Park SH, Becker-Catania S, Gatti RA, Crandall BF, Emelin JK, Vinters HV: Congenital olivopontocerebellar atrophy: report of two siblings with paleo- and neocerebellar atrophy. Acta Neuropathol 1998, 96:315-321.

36. Pittella JE, Nogueira AM: Pontoneocerebellar hypoplasia: report of a case in a newborn and review of the literature. Clin Neuropathol 1990, 9:33-38.

37. Budde BS, Namavar Y, Barth PG, Poll-The BT, Nurnberg G, Becker C, van

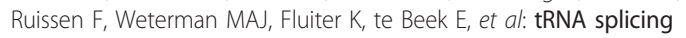
endonuclease mutations cause pontocerebellar hypoplasia. Nat Genet 2008, 40:1113-1118.

38. Namavar $Y$, Chitayat D, Barth PG, van Ruissen F, de Wissel MB, Poll-The BT, Silver R, Baas F: TSEN54 mutations cause pontocerebellar hypoplasia type 5. Eur J Hum Genet 2011

39. Rankin J, Brown R, Dobyns WB, Harington J, Patel J, Quinn M, Brown G: Pontocerebellar hypoplasia type 6: A British case with PEHO-like features. Am J Med Genet A 2010, 152A:2079-2084

40. Simonati A, Cassandrini D, Bazan D, Santorelli FM: TSEN54 mutation in a child with pontocerebellar hypoplasia type 1. Acta Neuropathol 2011.

41. CBS: 2011 [http://www.cbs.nl/nl-NL/menu/home/default.htm].

42. Renbaum P, Kellerman E, Jaron R, Geiger D, Segel R, Lee M, King MC, LevyLahad E: Spinal muscular atrophy with pontocerebellar hypoplasia is caused by a mutation in the VRK1 gene. Am J Hum Genet 2009, 85:281-289.

43. Dubowitz V, Daniels RJ, Davies KE: Olivopontocerebellar hypoplasia with anterior horn cell involvement (SMA) does not localize to chromosome 5 q. Neuromuscul Disord 1995, 5:25-29.

44. Muntoni F, Goodwin F, Sewry C, Cox P, Cowan F, Airaksinen E, Patel S, Ignatius J, Dubowitz V: Clinical spectrum and diagnostic difficulties of infantile ponto-cerebellar hypoplasia type 1. Neuropediatrics 1999, 30:243-248

45. Weinberg AG, Kirkpatrick JB: Cerebellar hypoplasia in Werdnig-Hoffmann disease. Dev Med Child Neurol 1975, 17:511-516.

46. Steiman GS, Rorke LB, Brown MJ: Infantile neuronal degeneration masquerading as Werdnig-Hoffmann disease. Ann Neurol 1980, 8:317-324.

47. de Leon GA, Grover WD, D'Cruz CA: Amyotrophic cerebellar hypoplasia: a specific form of infantile spinal atrophy. Acta Neuropathol 1984, 63:282-286.

48. Kamoshita S, Takei Y, Miyao M, Yanagisawa M, Kobayashi S, Saito K: Pontocerebellar hypoplasia associated with infantile motor neuron disease (Norman's disease). Pediatr Pathol 1990, 10:133-142.

49. Chou SM, Gilbert EF, Chun RW, Laxova R, Tuffli GA, Sufit RL, Krassikot N Infantile olivopontocerebellar atrophy with spinal muscular atrophy (infantile OPCA + SMA). Clin Neuropathol 1990, 9:21-32.

50. Sztriha L, Johansen JG: Spectrum of malformations of the hindbrain (cerebellum, pons, and medulla) in a cohort of children with high rate of parental consanguinity. Am J Med Genet A 2005, 135:134-141.

51. Rudnik-Schoneborn S, Wirth B, Rohrig D, Saule H, Zerres K: Exclusion of the gene locus for spinal muscular atrophy on chromosome $5 \mathrm{q}$ in a family with infantile olivopontocerebellar atrophy (OPCA) and anterior horn cell degeneration. Neuromuscul Disord 1995, 5:19-23.
52. Grosso S, Mostadini R, Cioni M, Galluzzi P, Morgese G, Balestri P: Pontocerebellar hypoplasia type 2: further clinical characterization and evidence of positive response of dyskinesia to levodopa. J Neurol 2002, 249:596-600.

53. Agamy O, Ben ZB, Lev D, Marcus B, Fine D, Su D, Narkis G, Ofir R, Hoffmann $C$, Leshinsky-Silver $E$, et al: Mutations disrupting selenocysteine formation cause progressive cerebello-cerebral atrophy. Am J Hum Genet 2010, 87:538-544.

54. Kaufmann R, Straussberg R, Mandel H, Fattal-Valevski A, Ben-Zeev B, Naamati A, Shaag A, Zenvirt S, Konen O, Mimouni-Bloch A, et al: Infantile cerebral and cerebellar atrophy is associated with a mutation in the MED17 subunit of the transcription preinitiation mediator complex. Am J Hum Genet 2010, 87:667-670.

55. van de Kamp JM, Lefeber DJ, Ruijter GJ, Steggerda SJ, den Hollander NS, Willems SM, Matthijs G, Poorthuis BJ, Wevers RA: Congenital disorder of glycosylation type la presenting with hydrops fetalis. J Med Genet 2007, 44:277-280.

56. Stibler H, Stephani U, Kutsch U: Carbohydrate-deficient glycoprotein syndrome-a fourth subtype. Neuropediatrics 1995, 26:235-237.

57. Denecke J, Kranz C, Kleist-Retzow JC, Bosse K, Herkenrath P, Debus O, Harms E, Marquardt T: Congenital disorder of glycosylation type Id: Clinical phenotype, molecular analysis, prenatal diagnosis, and glycosylation of fetal proteins. Pediat Res 2005, 58:248-253.

58. Kranz C, Sun L, Eklund EA, Krasnewich D, Casey JR, Freeze HH: CDG-Id in two siblings with partially different phenotypes. Am J Med Genet A 2007, 143A:1414-1420.

59. Hart CE, Race V, Achouri Y, Wiame E, Sharrard M, Olpin SE, Watkinson J, Bonham JR, Jaeken J, Matthijs G, et al: Phosphoserine aminotransferase deficiency: a novel disorder of the serine biosynthesis pathway. Am J Hum Genet 2007, 80:931-937.

60. Scaglia F, Wong LJ, Vladutiu GD, Hunter JV: Predominant cerebellar volume loss as a neuroradiologic feature of pediatric respiratory chain defects. Am J Neuroradiol 2005, 26:1675-1680.

61. de Koning TJ, de Vries LS, Groenendaal F, Ruitenbeek W, Jansen GH, PollThe BT, Barth PG: Pontocerebellar hypoplasia associated with respiratorychain defects. Neuropediatrics 1999, 30:93-95.

62. Somer M: Diagnostic criteria and genetics of the PEHO syndrome. J Med Genet 1993, 30:932-936.

63. Riikonen R: The PEHO syndrome. Brain Dev 2001, 23:765-769.

64. Kirschner J, Bonnemann CG: The congenital and limb-girdle muscular dystrophies: sharpening the focus, blurring the boundaries. Arch Neurol 2004, 61:189-199.

65. Muntoni F, Voit T: The congenital muscular dystrophies in 2004: a century of exciting progress. Neuromuscul Disord 2004, 14:635-649.

66. Najm J, Horn D, Wimplinger I, Golden JA, Chizhikov W, Sudi J, Christian SL, Ullmann R, Kuechler A, Haas CA, et al: Mutations of CASK cause an Xlinked brain malformation phenotype with microcephaly and hypoplasia of the brainstem and cerebellum. Nat Genet 2008, 40:1065-1067.

67. Jissendi-Tchofo P, Kara S, Barkovich AJ: Midbrain-hindbrain involvement in lissencephalies. Neurology 2009, 72:410-418.

68. Poirier K, Saillour Y, Bahi-Buisson N, Jaglin XH, Fallet-Bianco C, Nabbout R, Castelnau-Ptakhine L, Roubertie A, Attie-Bitach T, Desguerre I, et al: Mutations in the neuronal ss-tubulin subunit TUBB3 result in malformation of cortical development and neuronal migration defects. Hum Mol Genet 2010, 19:4462-4473.

69. Tischfield MA, Cederquist GY, Gupta ML Jr, Engle EC: Phenotypic spectrum of the tubulin-related disorders and functional implications of diseasecausing mutations. Curr Opin Genet Dev 2011.

70. Messerschmidt A, Brugger PC, Boltshauser E, Zoder G, Sterniste W, Birnbacher R, Prayer D: Disruption of cerebellar development: potential complication of extreme prematurity. AJNR Am J Neuroradiol 2005, 26:1659-1667.

71. Messerschmidt A, Fuiko R, Prayer D, Brugger PC, Boltshauser E, Zoder G, Sterniste W, Weber M, Birnbacher R: Disrupted cerebellar development in preterm infants is associated with impaired neurodevelopmental outcome. Eur J Pediatr 2008, 167:1141-1147.

72. Trotta CR, Miao F, Arn EA, Stevens SW, Ho CK, Rauhut R, Abelson JN: The yeast tRNA splicing endonuclease: a tetrameric enzyme with two active site subunits homologous to the archaeal tRNA endonucleases. Cell 1997, 89:849-858. 
73. Paushkin SV, Patel M, Furia BS, Peltz SW, Trotta CR: Identification of a human endonuclease complex reveals a link between tRNA splicing and pre-mRNA 3' end formation. Cell 2004, 117:311-321.

74. Trotta CR, Paushkin SV, Patel M, Li H, Peltz SW: Cleavage of pre-tRNAs by the splicing endonuclease requires a composite active site. Nature 2006, 441:375-377.

75. Hopper AK, Phizicky EM: tRNA transfers to the limelight. Genes Dev 2003, 17:162-180.

76. Genomic tRNA database: 2010 [http://lowelab.ucsc.edu/GtRNAdb/].

77. Wickens M, Gonzalez TN: Molecular biology. Knives, accomplices, and RNA. Science 2004, 306:1299-1300.

78. Weitzer S, Martinez J: The human RNA kinase hClp1 is active on 3 transfer RNA exons and short interfering RNAs. Nature 2007, 447:222-226.

79. Trotta CR: Biochemistry: The big catch. Nature 2007, 447:156-157.

80. Weitzer S, Martinez J: hClp1: a novel kinase revitalizes RNA metabolism. Cell Cycle 2007, 6:2133-2137.

81. Kasher PR, Namavar Y, van TP, Fluiter K, Sizarov A, Kamermans M, Grierson AJ, Zivkovic D, Baas F: Impairment of the tRNA-splicing endonuclease subunit 54 (tsen54) gene causes neurological abnormalities and larval death in zebrafish models of pontocerebellar hypoplasia. Hum Mol Genet 2011, 20:1574-1584.

82. Ten Donkelaar HJ, Lammens $M$, Wesseling P, Thijssen HO, Renier WO: Development and developmental disorders of the human cerebellum. J Neurol 2003, 250:1025-1036.

83. Antonellis A, Green ED: The role of aminoacyl-tRNA synthetases in genetic diseases. Annu Rev Genomics Hum Genet 2008, 9:87-107.

84. Park SG, Kim HJ, Min YH, Choi EC, Shin YK, Park BJ, Lee SW, Kim S: Human lysyl-tRNA synthetase is secreted to trigger proinflammatory response. Proc Natl Acad Sci USA 2005, 102:6356-6361.

85. Hausmann CD, Ibba M: Aminoacyl-tRNA synthetase complexes: molecular multitasking revealed. FEMS Microbiol Rev 2008, 32:705-721.

86. Palioura S, Sherrer RL, Steitz TA, Soll D, Simonovic M: The human SepSecStRNASec complex reveals the mechanism of selenocysteine formation. Science 2009, 325:321-325.

87. Allmang $C$, Wurth $L$, Krol A: The selenium to selenoprotein pathway in eukaryotes: more molecular partners than anticipated. Biochim Biophys Acta 2009, 1790:1415-1423.

88. Bosl MR, Takaku K, Oshima M, Nishimura S, Taketo MM: Early embryonic lethality caused by targeted disruption of the mouse selenocysteine tRNA gene (Trsp). Proc Natl Acad Sci USA 1997, 94:5531-5534.

89. Scheper GC, van der Klok T, van Andel RJ, van Berkel CG, Sissler M, Smet J, Muravina TI, Serkov SV, Uziel G, Bugiani M, et al: Mitochondrial aspartyltRNA synthetase deficiency causes leukoencephalopathy with brain stem and spinal cord involvement and lactate elevation. Nat Genet 2007, 39:534-539.

90. Park SG, Schimmel P, Kim S: Aminoacyl tRNA synthetases and their connections to disease. Proc Natl Acad Sci USA 2008, 105:11043-11049.

91. Lukong KE, Chang KW, Khandjian EW, Richard S: RNA-binding proteins in human genetic disease. Trends Genet 2008, 24:416-425.

92. Cooper TA, Wan L, Dreyfuss G: RNA and disease. Cell 2009, 136:777-793.

93. Kolb SJ, Sutton S, Schoenberg DR: RNA processing defects associated with diseases of the motor neuron. Muscle Nerve 2010, 41:5-17.

94. Lemmens R, Moore MJ, Al-Chalabi A, Brown RH Jr, Robberecht W: RNA metabolism and the pathogenesis of motor neuron diseases. Trends Neurosci 2010, 33:249-258.

95. Lee JW, Beebe K, Nangle LA, Jang J, Longo-Guess CM, Cook SA, Davisson MT, Sundberg JP, Schimmel P, Ackerman SL: Editing-defective tRNA synthetase causes protein misfolding and neurodegeneration. Nature 2006, 443:50-55.

96. Dittmar KA, Goodenbour JM, Pan T: Tissue-specific differences in human transfer RNA expression. PLoS Genet 2006, 2:e221.

97. Morgane PJ, Miller M, Kemper T, Stern W, Forbes W, Hall R, Bronzino J, Kissane J, Hawrylewicz E, Resnick O: The Effects of Protein Malnutrition on the Developing Central Nervous System in the Rat. Neuroscience \& Biobehavioral Reviews 1978, 2:137-230.

98. De F, Varela O, Oropeza JJ, Bisiacchi B, Alvarez A: Effects of prenatal protein malnutrition on the electrical cerebral activity during development. Neurosci Lett 2010, 482:203-207.

99. Georgieff MK: Nutrition and the developing brain: nutrient priorities and measurement. Am J Clin Nutr 2007, 85:614S-620S.
100. Jordanova A, Irobi J, Thomas FP, Van Dijck P, Meerschaert K, Dewil M, Dierick I, Jacobs A, De Vriendt E, Guergueltcheva V, et al: Disrupted function and axonal distribution of mutant tyrosyl-tRNA synthetase in dominant intermediate Charcot-Marie-Tooth neuropathy. Nat Genet 2006, 38:197-202.

101. McLaughlin HM, Sakaguchi R, Liu C, Igarashi T, Pehlivan D, Chu K, lyer R, Cruz P, Cherukuri PF, Hansen NF, et al: Compound heterozygosity for lossof-function lysyl-tRNA synthetase mutations in a patient with peripheral neuropathy. Am J Hum Genet 2010, 87:560-566.

102. Belostotsky R, Ben-Shalom E, Rinat C, Becker-Cohen R, Feinstein S, Zeligson S, Segel R, Elpeleg O, Nassar S, Frishberg Y: Mutations in the mitochondrial seryl-tRNA synthetase cause hyperuricemia, pulmonary hypertension, renal failure in infancy and alkalosis, HUPRA syndrome. Am J Hum Genet 2011, 88:193-200.

103. Pierce SB, Chisholm KM, Lynch ED, Lee MK, Walsh T, Opitz JM, Li W, Klevit RE, King MC: Mutations in mitochondrial histidyl tRNA synthetase HARS2 cause ovarian dysgenesis and sensorineural hearing loss of Perrault syndrome. Proc Natl Acad Sci USA 2011.

104. Popow J, Englert M, Weitzer S, Schleiffer A, Mierzwa B, Mechtler K, Trowitzsch S, Will CL, Luhrmann R, Soll D, et al: HSPC117 is the essential subunit of a human tRNA splicing ligase complex. Science 2011, 331:760-764.

105. Calvin K, Li H: RNA-splicing endonuclease structure and function. Cell Mol Life Sci 2008, 65:1176-1185.

doi:10.1186/1750-1172-6-50

Cite this article as: Namavar et al:: Classification, diagnosis and potential mechanisms in Pontocerebellar Hypoplasia. Orphanet Journal of Rare Diseases 2011 6:50.

\section{Submit your next manuscript to BioMed Central and take full advantage of:}

- Convenient online submission

- Thorough peer review

- No space constraints or color figure charges

- Immediate publication on acceptance

- Inclusion in PubMed, CAS, Scopus and Google Scholar

- Research which is freely available for redistribution

Submit your manuscript at www.biomedcentral.com/submit
C) Biomed Central 